\title{
Book Review: International Handbook on the Economics of Integration
}

International Handbook on the Economics of Integration, edited by Miroslav Jovanović(2011), III volumes, total 1672 pages(Vol. I 560 pp, Vol. II 616 pp, Vol. III 496 pp) hard cover, Edward Elgar Publishing, 2011 ISBN Vol. I: 978184844370 9, Vol. II: 978184980426 4, Vol. III: 978184980427 1, 3 volume set: 9781849804288.

Isidora Ljumović

Economic Institute, Belgrade, Serbia

Since the end of the Second World War, economic integration has been regarded as being one of the most important global economic policies. Its relevance has not diminished and most countries, especially those that are developing, consider it to be a long-term strategy. Integration is present in various forms all around the world on a wide scale of depth and geographical coverage, but the largest, strongest and deepest forms exist in developed countries with the European Union (EU) leading the way. The most important effects of economic integration can be seen in the field of economic growth and development, with benefits that include lower transaction costs, lower investment risk, market expansion, pooling of regional resources, economies of scale, efficient allocation of resources and many more. However, over the period of their establishment and development examples of economic integration from all around the world have raised numerous questions and problems - both theoretical and applied - which primarily have to be dealt with by policymakers. This handbook attempts to provide answers for some of these problems/questions, while at the same time offering new perspectives and ideas.

European markets and European integration were hit heavily by the international financial meltdown of 2008. Its lasting impact leads to various questions concerning the survival of the Euro as a single currency, and even to questions about European integration in general. It stands to reason that understanding the essence of European integration in all of its facets would help greatly in dealing with the consequences of the current crisis. With this in mind, this three-volume handbook serves as an explicit attempt to issue a warning about how the future of Europe may look if no changes are made.

\footnotetext{
* Corresponding Author: Isidora Ljumović; Economic Institute, Kralja Milana 16, Beograd, Serbia; Tel: +381 113613458, E-mail: isidora.ljumovic@ecinst.org.rs.
} 
The handbook contains proposals and advice which policymakers should take into consideration when attempting to cope with a crisis; not only at the EU level, but also on a global scale. The continuing issues and patterns of the financial crisis have been incorporated since it's the handbook was publicised in 2011, when its original material and chapters were put together. When we compare it to other similar literature we can see that the editor, Miroslav Jovanović, tried to convene eminent authors from all over the world and from different generations in order to solve issues that have not been given satisfactory treatment elsewhere. The overriding impression is that he succeeded in his efforts.

Jovanović holds numerous prestigious scholarships. He is a prominent scientist and scholar who shuttled between European and Canadian universities during his academic education before earning his $\mathrm{PhD}$ at the University of Belgrade. Over the course of his academic career he has given public lectures and courses at many universities in Europe, China, Japan and the United States. Aside from his academic career, Jovanović currently works for the United Nations Economic Commission for Europe (UNECE) in Geneva, Switzerland and lectures at the Global Studies Institute of the University of Geneva. This unique situation makes him well placed to write and edit on the topic of integration from a neutral point of view. As an author of several books and numerous articles on the economics of transnational corporations, spatial location and economic integration, he was without a doubt the right person to edit the three volumes of this handbook and to contribute his own chapter. In the foreword to this handbook Nicolas Levrat, director of the European Institute of the University of Geneva, explained in more detail Jovanović's competency as contributor and editor. He noted that Jovanović has "both an extraordinary observation position - at the heart of the most advanced regional economic integration process going on in Europe - and the proper distance for academic observation, since UNECE is not directly part of the mainstream process of the economic integration taking place in the EU, and Switzerland is not a member state of the EU" (p. xii).

The International Handbook on the Economics of Integration is an edited set of three volumes which presents a rich collection of contributions that will be valuable to economists, scholars and practitioners. The aim of this handbook is to reveal the issues most relevant for helping the reader to achieve a firm understanding of the role international integration plays in influencing economy. As Jovanović states, the "objective of the handbook is to offer an insight and introduction into the principal contemporary economic issues linked with international economic integration" (p. xix). The editor achieved this goal by shaping this handbook into a diverse array of articles and themes presented by eminent scholars, scientists and practitioners. The handbook not only presents a survey of relevant literature but also offers new perspectives and ideas of which policymakers should be aware. Some of the contributing authors are pioneers in their particular fields of integration economics.

The economics of integration is an old economic discipline, dating back to the 1950s. Many books that cover the discipline's various issues have been written over the years but until this handbook's publication a comprehensive analysis of these themes had yet to emerge. The 
handbook's introductory section consists of a foreword by Nicolas Levrat, an introductory note by United Nations Conference on Trade and Development (UNCTAD) Deputy SecretaryGeneral Petko Draganov and an acknowledgements section by the editor. This is followed by three volumes that each deal with three different aspects of the economics of integration.

The first volume, General Issues and Regional Groups, traces the foundation for the economics of integration and features 22 chapters from 26 authors. It covers two broad themes: general integration issues and regional integration groups. General integration issues deal with the subjects of regional trade agreements, global trade, multilateralism, regionalism, globalization, limits and barriers to liberalization and the role of technology in globalization. Regional integration groups, however, cover integration arrangements in different parts of the world.

The first volume provides a natural path to the second volume, Competition, Spatial Location of Economic Activity and Financial Issues, which tracks three broad themes in 20 chapters from 34 contributors. The first part analyses competition and industrial policy from a European standpoint while the second deals with the geography of production, spatial effects, industry allocation and some practical considerations. The last section introduces international financial organizations and the different monetary and fiscal issues that occur across the EU and at the global level.

The third volume, Factor Mobility, Agriculture, Environment and Quantitative Studies, comprises 19 chapters from 32 authors. It also covers three themes. Factor mobility makes up two sections with the first section dealing with issues regarding transnational corporations. The second section contains an analysis of labour migration. The third volume's second theme is related to the importance of agriculture and environment in economic integration. Finally, there are seven articles that analyse the empirical relevance of economic integration and its benefits. Every chapter is followed by a summary, enabling a concise overview of the subject. Coverage in these edited volumes is remarkably broad, and they contain analysis and discussion of many previously unexplored themes.

\section{Volume I - General Issues and Regional Groups}

The first author of Volume I, Fiorentino, draws attention to regional trade agreements and provides an update on recent trends and developments with an outlook towards the changing landscape of the future. Making a distinction between the main trends and characteristics of regional trade agreements at both regional and global levels, Fiorentino goes on to emphasize that transparency is the first step to unravelling the global puzzle of preferential trade relations. Baldwin, in the second chapter, provides an update to his 2006 article and addresses what the final steps of global trade - multilateralisation - could look like. He emphasises the role of political economy and the World Trade Organization (WTO) and also provides a background on how regional trade agreements (or the "spaghetti bowl", as he calls it) can pave the way 
for global free trade. Lipsey and Smith provide a background to the historical evolution of regional trade agreements and multilateral trading systems, followed by an economic analysis of regional trade agreements and political economy effects. The key message expresses their optimism that the liberalisation of regional trade agreements will eventually lead to further multilateral liberalisation.

The fourth chapter by Ethier contrasts contemporary and old regionalism and concludes by applying a model to show that contemporary regionalism reflects the success of multilateralism. Georgiev, in the fifth chapter, examines the legal relationship between WTO agreements and the agreements of international economic integration. He also provides a legal analysis of Article XXIV of the General Agreement on Tariffs and Trade (GATT). Wonnacott examines a nation's need to evaluate new issues, such as the hub-and-spoke complications possible when a country does not join a regional union but instead opts to sign a separate bilateral agreement with only one member of the union. The following chapter by Wonnacott and Wonnacott explores the implications of trade gains that can be reaped from export or import. Cadot, Melo and Portugal-Pérez give an extensive overview of the rules of origin and present a framework that can help the reader understand how these rules affect the utilisation of preferences. The ninth chapter, written by Fratianni and Marchionne, attempts to answer what factors limit the expansion of cross-border transactions. Through applying the gravity equation model they find that the two big drivers of international trade are incomes and distance. Lipsey establishes a link between globalisation and technology and gives a historical overview of the relationship's development and its impact on global trade. Jovanović contributes in the eleventh chapter by explaining and critically addressing the process of globalisation, attempting to unify its definition and meaning since confusion and disagreement are rife in this field. The prominent idea of this chapter is that even though it was thought that globalisation would be of benefit to everyone, its downsides are becoming more apparent as time marches on.

Sidjanski opens the second part of first volume with an excellent article elaborating on how the Lisbon Treaty was as a turning point in the European integration process. This chapter is followed by an overview of EU policies and policymaking by Nicolaides. Having explained these instruments he concludes that the EU is the most extensive and ambitious cooperation attempt in history. Tirkides and Theophanous perform an appraisal of the Union for the Mediterranean's countries and of the group's relationship with the EU, with emphasis placed on Germany's reaction to the new Barcelona Process. The following chapters deal with principal integration arrangements from different parts of the world. Smith examines the North American Free Trade Agreement (NAFTA) in the fifteenth chapter. He argues that NAFTA is a done deal, or as he says a "fait accompli", which has the potential to change future structures and processes. Pomfret then analyses regional integration in East Asia from a historical standpoint and argues that it has been driven by the emergence of regional value chains. He also gives a background for the weak integration witnessed in East Asia before the Asian crisis of 1997.

The seventeenth chapter contains a contribution from Hiratsuka, who discusses recent 
developments in economic integration and institutional cooperation in East Asia. He concludes that East Asia has managed to maintain a high level of integration and that in many ways it is a "world factory" for many products. Frischtak makes an assessment of the integration efforts that have taken place in South America and their associated economic dynamism. He examines whether the creation of free trade in South America is possible, what the potential benefits could be and who would be the main enablers of this process. Hira, in the nineteenth chapter, moves takes a look at Latin America with a focus on the problems of structural adjustment in the region. He comes to the conclusion that structural adjustments have influenced the developing world on various levels and have paved the way for multilateral and regional integration. Borgatti then explores economic integration in Sub-Saharan Africa. After an extensive review she concludes that Sub-Saharan Africa would have numerous development opportunities if it were to follow the examples of Japan and the East Asian model - the flying-geese paradigm. The last two chapters, contributed by Hadhri and Broude, are related to integration in the Arab world. Hadhri addresses the challenges of globalisation and new regionalism and tries to outline the strategy they believe is necessary for speeding up economic integration among Arab countries. The chapter rounds off with Broude reviewing past and present bilateral and regional initiatives, followed by a description of economic and regulatory diversity in the Middle East and North Africa.

\section{Volume II - Competition, Spatial Location of Economic Activity and Financial Issues}

The handbook's second volume starts with a chapter from Curzon Price, who draws attention to institutional competition in the EU and singles out the harmonisation of a wide range of EU laws and regulations as being an inevitable future issue. In her opinion, the most important area of harmonisation at the EU level will be fiscal policy. The second chapter comes from Pitelis and Kelmendi and casts light on alternative perspectives to European industrial and competition policies. The chapter also provides a critical overview of current EU policies. This is followed by a comprehensive study by Buigues and Meiklejohn of network industries in the EU, in which they conclude that even if many positive developments exist, the extent to which network industries have opened up remains limited. Cuervo-Cazurra and Un then try to establish a link between economic integration and the technological capabilities of domestic firms. The focus of their piece is the positive relationship between economic integration and the technological capabilities of domestic firms. In the last chapter of the second volume's first part, Castellacci provides a perspective of evolutionary economics when compared to a mainstream heterogeneity model.

In the sixth chapter, Tharakan and Thisse tackle trade and economic geography in order to evaluate the effects of market integration on the global economy. The seventh chapter, from Camagni and Capello, provides a theoretical background to the relationship between regional 
growth and location. Behrens, Mion and Ottaviano then attempt to make predictions on the effects of new trade theory on globalisation, firms and countries. In the ninth chapter, Amiti uses a formal model to examine how the sequence of trade liberalisation can affect industrial location. She argues that reducing tariffs on only one part of the production chain can increase the attractiveness of a location and have lasting effects. Forslid also uses a model (a multicountry version of the Footloose Capital [FC] model, where he adds a third region to the existing two-region model) to explore the interaction between economic integration and some typical regional policies.

The eleventh chapter comes from Fujita and Hamaguchi. Based on their previous work in East Asia, they explore the impact of regional economic integration on spatial distribution with regard to both agglomeration and disparities and conclude that in cases where large regional disparities are present, less-developed countries can benefit from regional integration. Litzel and Möller argue that economic integration should not be looked at from only a crossborder perspective but that great importance lies in intra-regional cooperation between firms and supporting institutions. The authors then conduct an analysis of the Nuremberg region and conclude that intra-regional integration can have as many benefits as supra-regional integration. Marin uses empirical data to present evidence of how the skilled workforces of Austria and Germany are dealing with Eastern European enlargement. She highlights how employees in Austrian and German firms have suffered significant layoffs - multinationals are outsourcing their activities to Eastern Europe, because of the cheap skilled labour, which, in turn, significantly affects employees in Austria and Germany. Linders, de Groot, Raymond and Nijkamp then shed light on the importance of geographic distance in trade. Unlike scholars who argue the existence of a distance-decay effect, the authors point to the opposite and back up their claims through the application of a meta-analysis.

Part three covers monetary and fiscal issues affecting international integration and starts with a chapter from Williamson on the history, function and possible future role of the International Monetary Fund (IMF) in international relations. In the sixteenth chapter, Praussello analyses the long-term stability and future of the European Monetary Union (EMU) and points to the possibility of dangerous asymmetric shocks that could thwart EMU's progress and lead to monetary disintegration. Whalley debates the international taxation of investment income from a perspective of existing arrangements and devises a four-step puzzle of a transborder capital income tax treatment. The economic aspects and existing legal framework of European financial integration are analysed by Gortsos in the eighteenth chapter, while Vanistendael provides a comprehensive analysis of fiscal integration in EU. The last chapter, from McCarthy, van Doorn and Unger, deals with tax competition and the harmonisation of corporate tax rates in Europe. They consider tax competition to be harmful and postulate that it has to be solved by some other means, rather than through tax rate harmonization. 


\section{Volume III - Factor Mobility, Agriculture, Environment and Quantitative Studies}

The third volume of the International Handbook on the Economics of Integration consists of three parts, the first of which deals with factor mobility and is divided into two sections. Transnational corporations are discussed in first six chapters, while the following two concentrate on labour migration. Pitelis starts by examining the role of foreign direct investment (FDI) and multinationals in economic integration. Following a thorough theoretical overview he concludes that FDI and clusters have greater importance for transition countries in their catching up. In the second chapter, Dunning and Clegg analyse what the countries that joined the EU in its fifth enlargement (Eastern European countries) have gained in terms of higher growth rates and enhancement of competitiveness. Letto-Gillies examines how different regulatory regimes between countries can create advantages for transnational corporations. Within the EU, transnational corporations (TNCs) have both an integration and fragmentation role, and it is up to the governments of EU states to develop policies and strategies that channel TNCs towards achieving socially and economically desirable goals. Rugman and $O h$ question the scope metrics and attempt to bring about a better framework for establishing links between international business theory and empirical research by applying scale metrics. By examining the world's 500 largest firms, they conclude that these firms mostly operate within their home region, while only one third of their sales and assets originate from abroad. The fifth chapter Ando addresses the two principles of economic integration with an emphasis on Japan's multinational enterprises. Safarian then explores the issue of transnational corporations and examines the nature and reasons for the international mergers and acquisitions made by traditional firms, private equity firms, hedge funds and state-owned enterprises (Sovereign Wealth Funds). He also provides a theoretical background for the motives and effects of different types of FDI. Chapters seven and eight cast light on the issue of labour migration. Zimmermann and Constant make a connection between migration, ethnicity and economic integration. They deal with several of the problems faced by immigrants, such as assimilation, labour force participation and remuneration. This chapter is followed by a proposal from Djajić to reform the system of international migration, arguing that the existing international migration system is heavily restricted and that a lot more could be done to improve the efficiency of labour allocation between countries.

In part two of the third volume van den Noort starts with an introduction to European integration and agricultural protection. The chapter is based mainly on research relating to Common Agricultural Policy (CAP) in the EU. The next chapter, by Silvis and Jongeneel, can be considered to be a follow-up to the previous chapter as it explores in detail the various reforms that have taken place in CAP. However, in the eleventh chapter Anderson and Valenzuela cast a different light on agricultural policy and through their analysis take the view that it is a barrier to global economic integration. Unlike many other authors who have dealt 
with agriculture, the following chapter by Tosun and Knill draws attention to the impact of economic integration on environmental policy.

The handbook's final section quantifies the effects of integration and starts off with a chapter from Grimwade, Mayes and Wand which contains a critical overview of quantitative models. They elaborate on how different models can lead to different conclusions and explain how crisis periods offer the best opportunities to test these models. In the next chapter, Badinger and Breuss provide a brief history of European post-war integration and conclude that EU enlargement was a win-win situation. This is followed by a chapter from Le, Minford and Nowell, in which they try to estimate the extent and cost of EU protectionism. They challenge the general consensus that the EU is a mechanism for creating a "competitive single market" and argue that protectionism in agriculture, manufacturing and services brings about a waste of resources of up to 3 per cent of GDP. Hagen and Mohl then provide an econometric survey of EU Cohesion Policy. They were not able to find a clear outcome and express their opinion that empirical results are mixed if not somewhat contradictory. In the seventeenth chapter Hufbauer and Adler conduct a trade analysis in order to evaluate the contribution of policy liberalization and integration in the United States to the country's GDP and merchandise trade growth. Rose then adapts a standard "gravity" model in order to quantify the effects that membership in the WTO and the General Agreement on Tariffs and Trade (GATT) have on international trade, and impresses his pessimism concerning the existence of positive effects in his research. The last chapter in this handbook, written by Marchetti using a standard gravity model, provides analysis of the quantitative effects of integration agreements on bilateral trade in services.

This handbook provides a comprehensive tour and in-depth analysis of the principal economic dimensions of economic integration and the global economy. Due to diverse range of themes dealt with by the handbook's authors it is inevitable that the reader may agree or disagree with the expressed views, but in this lies the handbook's significance in that it will inspire more research, articles and books on the subjects covered. In sum, the handbook provides a wide array of source material and information for potential future research. I would recommend this handbook to every university library and anyone, scholars and practitioners alike, interested in the far-reaching strands of international economics and integration.

Received 13 February 2013, Revised 04 April 2013, Accepted 07 June 2013 